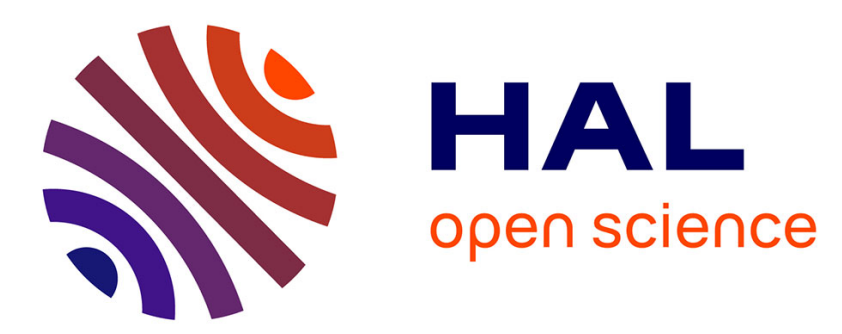

\title{
Soil enzyme activities as potential indicators of soluble organic nitrogen pools in forest ecosystems of Northeast China
}

\author{
Yang, Zhu, Yan, Zhang
}

\section{- To cite this version:}

Yang, Zhu, Yan, Zhang. Soil enzyme activities as potential indicators of soluble organic nitrogen pools in forest ecosystems of Northeast China. Annals of Forest Science, 2012, 69 (7), pp.795-803. 10.1007/s13595-012-0198-z . hal-00930847

\section{HAL Id: hal-00930847 https://hal.science/hal-00930847}

Submitted on 1 Jan 2012

HAL is a multi-disciplinary open access archive for the deposit and dissemination of scientific research documents, whether they are published or not. The documents may come from teaching and research institutions in France or abroad, or from public or private research centers.
L'archive ouverte pluridisciplinaire HAL, est destinée au dépôt et à la diffusion de documents scientifiques de niveau recherche, publiés ou non, émanant des établissements d'enseignement et de recherche français ou étrangers, des laboratoires publics ou privés. 


\title{
Soil enzyme activities as potential indicators of soluble organic nitrogen pools in forest ecosystems of Northeast China
}

\author{
Kai Yang $\cdot$ Jiaojun Zhu $\cdot$ Qiaoling Yan $\cdot$ Jinxin Zhang
}

Received: 21 January 2012 / Accepted: 17 February 2012 /Published online: 13 March 2012

(C) INRA / Springer-Verlag France 2012

\begin{abstract}
- Context Soluble organic nitrogen is considered to reflect the effect of forest types on soil nitrogen status. As a major process affecting the soil-soluble organic nitrogen pool, degradation of insoluble organic nitrogen in the production of soluble organic nitrogen is mediated by a suite of soil enzymes.

- Aims This study aims to examine soil-soluble organic nitrogen pools and their relationships with the activities of soil enzymes in natural secondary forest stands and adjacent larch plantation stands.

- Methods Four pairs of larch plantation stands and secondary forest stands were randomly selected from a mountainous area, and the top $15 \mathrm{~cm}$ of the mineral soils were sampled from each field.

- Results The soil-soluble organic nitrogen concentrations were up to 2-fold greater in the secondary forest stands than in the larch plantation stands, whereas the ratio of soluble organic nitrogen/total nitrogen was comparable between the two forest types. The concentrations of soluble organic nitrogen
\end{abstract}

Handling Editor: Erwin Dreyer

Contribution of the co-authors Kai Yang: designed and ran the experiment, analyzed the data, and wrote and revised the manuscript Jiaojun Zhu: supervised the experiment design and data analysis and wrote and revised the manuscript

Qiaoling Yan: revised the manuscript

Jinxin Zhang: gave the help in experiment and edited the manuscript

K. Yang $\cdot$ J. Zhu $\cdot$ Q. Yan $\cdot$ J. Zhang

Qingyuan Experimental Station of Forest Ecology,

Institute of Applied Ecology, Chinese Academy of Sciences,

Shenyang 110016, People's Republic of China

K. Yang $\cdot$ J. Zhu $(\bowtie) \cdot$ Q. Yan

State Key Laboratory of Forest and Soil Ecology,

Institute of Applied Ecology, Chinese Academy of Sciences,

Shenyang 110164, People's Republic of China

e-mail: jiaojunzhu@iae.ac.cn were positively correlated with approximately 2 -fold differences in urease and protease activities, a 1.2-fold difference in $\mathrm{N}$ acetyl- $\beta$-glucosaminidase and a 1.7 -fold difference in L-asparaginase between the two forest types.

- Conclusions Our results suggest that relationships between soil-soluble organic nitrogen and enzyme activities are independent on sampling time, and that the soil enzyme activities can be used as potential indicators of soil soluble organic nitrogen pools in the temperate forest ecosystem.

Keywords Soil-soluble organic nitrogen - Enzyme activity . Natural secondary forest $\cdot$ Larch plantation

\section{Introduction}

Soil-soluble organic nitrogen (SON), defined as organic forms of $\mathrm{N}$ extracted by water or salt solutions (e.g., $\mathrm{KCl}$ and $\mathrm{K}_{2} \mathrm{SO}_{4}$ ), consists of a mixture of structurally diverse $\mathrm{N}$-containing compounds (Chen and Xu 2008; Murphy et al. 2000). As the chief component of soluble nitrogen, soil SON plays a vital role in $\mathrm{N}$ cycling and therefore in determining soil $\mathrm{N}$ availability in forest ecosystems. More than $50 \%$ of the $\mathrm{N}$ in soil solution has been reported to occur in organic form (Yu et al. 2002), and certain plant species can directly obtain and utilize amino acids as a principal source of N (Näsholm et al. 1998; Farrell et al. 2011). Moreover, a recent study (LeDuc and Rothstein 2010) concluded that the dominance of plant-available organic nitrogen shifts with the age of the forest stand. A review of soil SON studies indicates that the SON originating from different forest types, forest stand ages, or soil types may vary in its quality, quantity, and biodegradability (Burton et al. 2007a). Thus, the mechanisms responsible for generating soil SON include complex biotic and abiotic processes (Chen and $\mathrm{Xu}$ 2008). In biotic processes, SON can be directly produced from 
microbial turnover and indirectly through microbial generation of extracellular enzymes (Neff et al. 2003). However, as both plants and soil microorganisms may compete for the organic nitrogen in the soil (Kaye and Hart 1997), it is also possible that the SON pools may vary spatially within the forest ecosystem because of variation in microbial population density and activity among different forest types.

$\mathrm{SON}$ is hypothesized to represent a transitional phase of the transformation of $\mathrm{N}$ between soil insoluble organic $\mathrm{N}$ and inorganic $\mathrm{N}\left(\mathrm{NH}_{4}{ }^{+}-\mathrm{N}\right)$ (Schimel and Bennett 2004). During soil $\mathrm{N}$ mineralization, soil $\mathrm{N}$-degrading enzymes that use different substrates are the mediators and catalysts of biochemical processes, and the different enzymes involved in different stages of organic $\mathrm{N}$ degradation will not necessarily respond in the same way (Sinsabaugh et al. 1991). Therefore, the assessment of different $\mathrm{N}$-degrading enzymes can provide information on the status of the key reactions that participate in the regulation of $\mathrm{N}$ transformation in soils. Because enzyme activities determine the rate-limiting steps in organic matter degradation, correlations between soil organic carbon and enzyme activities are frequently observed (Boerner et al. 2005; Sinsabaugh et al. 2008). However, the relationship between soil SON and soil enzyme activities has received little attention (Xing et al. 2010).

It is well known that the characteristics of vegetation influence soil $\mathrm{N}$ cycling in forest ecosystems. The SON may regulate the rate of $\mathrm{N}$ transformation in the soil, i.e., the rate of ammonification and nitrification, by affecting the substrate associated with different plant species. Therefore, the effects of forest types on soil SON pools have recently attracted increasing attention (Zhu and Carreiro 2004). The forest type can potentially affect the concentrations of soil SON through, e.g., the alteration of soil microbial activity and microbial communities (Booth et al. 2005) and changes in the quantity and quality of plant residues returned to the soil (Burton et al. 2007a). Note that the soil SON from the organic layer in different forest types can influence forest productivity (Kranabetter et al. 2007) as well as microbial activity and $\mathrm{N}$ availability in the mineral layer (Kalbitz et al. 2000). Studies that examined soil SON variation in broadleaved forests and coniferous forests within a forest ecosystem appear to produce inconsistent results. One study reported that concentrations of soil SON did not differ significantly between silver birch (broadleaf species) and Norway spruce (conifer species) (Smolander and Kitunen 2002), whereas another study showed that the concentrations of soil SON in broadleaved forests were higher than those in the coniferous forests (Xing et al. 2010). It is possible that the inconsistent findings about soil SON in different plant species may be due to differences in microbial transformation processes (Chen and $\mathrm{Xu} 2008$ ). Many studies have demonstrated that the effects of vegetation types on soil nutrient storage or availability can be detected by quantifying enzyme activity (Freeman et al. 2001; Weand et al. 2010). For example, soil phenol oxidase activity, involved in lignin degradation, is used as a potential indicator of the variation in soil organic carbon storage in northern peatlands (Freeman et al. 2001). Our previous study also indicated that soil acid phosphatase activity could indicate the soil $\mathrm{P}$ availability in natural secondary forests and larch plantations (Yang et al. 2010). Thus, knowledge of several N-degrading enzyme activities may provide information on the variation in soil SON with different forest types.

The temperate forest in Northeast China, primarily including secondary forests and plantations, represents more than one third of the forest area and standing tree volume in the entire nation and provides both timber and environmental benefits. Consequently, the temperate forest represents an important ecosystem associated with the nation's carbon accumulation. Soil nutrients are a key factor that influences forest productivity. Many efforts have been made to understand the ecological processes occurring in the soil of natural secondary forests and larch plantations (Yang et al. 2010). However, the soil nitrogen dynamics, such as the soil SON pool size and enzyme activity associated with $\mathrm{N}$ cycling in these forests, generally remain uncertain. Using adjacent natural secondary forest (SF) stands and larch plantation (LP) stands in the montane region of eastern Liaoning Province of Northeast China, we compared the SON pool and enzyme activities associated with $\mathrm{N}$ degradation between the SF stands and the LP stands. We hypothesized that soil SON varies with forest types and that this variation in the soil SON could be partially explained by the activities of $\mathrm{N}$-degrading enzymes. The objectives of this study were (1) to compare the soil SON pool and the activities of Ndegrading enzymes, including $N$-acetyl- $\beta$-glucosaminidase, urease, L-asparaginase, and protease between the SF stands and the LP stands and (2) to determine the relationships between the soil SON and N-degrading enzyme activities in the SF stands and the LP stands.

\section{Materials and methods}

\subsection{Study site and soil sampling}

The study was conducted at the Qingyuan Experimental Station, Institute of Applied Ecology, Chinese Academy of Sciences, located in a mountainous area of Liaoning Province, China (latitude $41^{\circ} 51^{\prime} \mathrm{N}$, longitude $124^{\circ} 54^{\prime} \mathrm{E}$, elevation 500 $1,100 \mathrm{~m}$ above sea level). The climate of the region is a continental monsoon type with a humid and rainy summer and a cold and dry winter. The mean annual air temperature varies between 3.9 and $5.4^{\circ} \mathrm{C}$, and the maximum and minimum temperatures are 36.5 and $-37.6^{\circ} \mathrm{C}$. The annual precipitation fluctuates between 700 and $850 \mathrm{~mm}$, with more than $80 \%$ falling during June-August. The growing season is from early April to late October (Zhu et al. 2007). 
The study site had been originally occupied by primary mixed broadleaved-Korean pine forests until the 1930s and subsequently subjected to decades of unregulated timber removal. Large-scale burning was conducted in the early 1950s. These fires completely removed the original forests, and the site was occupied by secondary forests with naturally regenerating broadleaved native tree species. Since the 1960s, patches of the natural secondary forests were partially cleared and replaced by larch (Larix olgenis or Larix kaempferi [Lamb.] Carr.) plantations. The natural secondary forests consisted of Fraxinus rhynchophylla, Juglans mandshurica, Phellodendron amurense, Quercus mongolica, and Acer mono in the tree layer, Acer mandshricum, Acer triflorun, Acer tegmentosum, and Syringa amurensis in the understory component, and Cardamine leucantha, Allium monanthum, Arisaema amurense, and Polygonatum involucratum in the herbage component. The larch plantations contain Acer tegmentosum, Acer pseudosieboldianum, Schisandra chinensis, Syringa wolfi, and Acanthopanax senticosus in the shrub layer and C. leucantha, Rubia sylvatica, and Spuriopimpinella brachycarpa in the herbage layer.

Four paired stands of natural secondary forests and adjacent larch plantations 35-45 years old were randomly chosen from separate watersheds over an area of 100 ha of experimental fields, with slopes $<15^{\circ}$ and altitudes ranging from 589 to $836 \mathrm{~m}$ above sea level. The area of each paired stand ranged from $\sim 3$ to 5 ha. Four paired stands of natural secondary forests and larch plantations were selected with different landforms (aspects and altitudes). The chosen four paired stands in two forest types on various landforms can stand for the general characteristics of the study area. A fixed $30 \times 30 \mathrm{~m}$ plot was established in each SF and LP stand for collecting soil samples. The soil is a typical brown forest soil, classified as Udalfs according to the second edition of the USDA soil taxonomy. The soil textures in the SF stands and LP stands were similar, averaging $25.6 \%$ sand, $51.2 \%$ silt, and $23.2 \%$ clay. In June (summer) and October (autumn) 2010, 15 soil cores (5 cm diameter) were randomly taken from each plot after the removal of surface plant litter, sectioned into $0-5$ and 5-15 cm depths, and then mixed thoroughly to obtain a homogeneous sample for each depth in a given stand. The soil samples were sieved $(<1.7 \mathrm{~mm})$, cleaned of visible plant and root residues, and stored at $4^{\circ} \mathrm{C}$ for later analyses.

\subsection{Analysis of selected soil properties}

The soil $\mathrm{pH}$ was estimated in a 1:2.5 soil-water mixture. The gravimetric soil water content was calculated from the mass loss after drying at $105^{\circ} \mathrm{C}$ until the soil remained at a measured constant weight. The SOC and total N (TN) were analyzed with dry combustion on a Vario EL III elemental analyzer (Elementar Analysensysteme Comp., Hanau, Germany). The soil microbial biomass $\mathrm{C}$ and $\mathrm{N}$ were determined using the chloroform fumigation extraction method (Brookes et al. 1985; Vance et al. 1987). The selected soil and microbial properties for the SF stands and LP stands are listed in Table 1.

\subsection{Soluble organic $\mathrm{N}$ in soil}

The soil SON in water and hot-water extracts was determined with modifications of the methods described by Chen et al. (2005). In brief, water extracts were prepared by mixing $10 \mathrm{~g}$ (dry weight equivalent) of field moist soil and $40 \mathrm{ml}$ of distilled water (soil/water ratio 1:4) on an end-to-end shaker for $1 \mathrm{~h}$ and filtering through Whatman no. 42 filter paper and subsequently through a $0.45-\mu \mathrm{m}$ filter membrane. For hotwater extracts, $10 \mathrm{~g}$ (dry weight equivalent) of field moist soil was mixed with $40 \mathrm{ml}$ of water in a tube, and the tube was placed in a hot-water bath for $18 \mathrm{~h}$ at $70^{\circ} \mathrm{C}$. The tubes were subsequently shaken for $5 \mathrm{~min}$ on an end-to-end shaker and filtered through Whatman no. 42 filter paper followed by a $0.45 \mu \mathrm{m}$ filter membrane. The concentrations of $\mathrm{NH}_{4}{ }^{+}-\mathrm{N}$ and $\mathrm{NO}_{3}{ }^{-}-\mathrm{N}$ in the extracts were analyzed with an autoanalyzer (AutoAnalyzer III, Bran+Luebbe GmbH, Germany). The concentration of total soluble $\mathrm{N}$ (TSN) in the same sample was determined with a Shimadzu TOC-TN analyzer (Shimadzu Corp., Kyoto, Japan). The SON was calculated as the difference between TSN and the sum of $\mathrm{NH}_{4}{ }^{+}-\mathrm{N}$ and $\mathrm{NO}_{3}{ }^{-}-\mathrm{N}$. To improve the accuracy, each soil was analyzed in duplicate.

\subsection{Soil enzyme activities}

$N$-acetyl- $\beta$-glucosaminidase activity was determined using the substrate $N$-acetyl- $\beta$-glucosaminide. Soil ( $0.5 \mathrm{~g}$ fresh soil) was incubated for $1 \mathrm{~h}$ at $37^{\circ} \mathrm{C}$ with $4 \mathrm{ml}$ of $50 \mathrm{mM}$ sodium acetate buffer and $1 \mathrm{ml}$ of the substrate solution. The reaction was stopped, and color was allowed to develop by the addition of $1 \mathrm{ml}$ of $0.5 \mathrm{M} \mathrm{CaCl}_{2}$ and $4 \mathrm{ml}$ of $0.5 \mathrm{M} \mathrm{NaOH}$. The reaction products were filtered, and the filtrates were analyzed colorimetrically at $410 \mathrm{~nm}$. The enzyme activity is expressed as micromoles of $p$-nitrophenol produced per hour per gram of soil.

Urease activity was estimated by mixing $5 \mathrm{~g}$ fresh soil, $9 \mathrm{ml}$ of $50 \mathrm{mM}$ Tris buffer and $1 \mathrm{ml}$ of the substrate solution followed by incubation for $2 \mathrm{~h}$ at $37^{\circ} \mathrm{C}$. The reaction was stopped by the addition of $35 \mathrm{ml}$ of $2.5 \mathrm{M} \mathrm{KCl} / 0.32 \mathrm{mM}$ $\mathrm{Ag}_{2} \mathrm{SO}_{4}$ solution. The ammonia formed was distilled and collected in boric acid mixed indicator solution and titrated with $5 \mathrm{mM} \mathrm{H}_{2} \mathrm{SO}_{4}$ (Tabatabai and Bremner 1972). The enzyme activity was expressed in micromoles of ammonium released per hour per gram of soil.

L-asparaginase activity was measured following a method developed by Frankenberger and Tabatabai (1991). Soil (5 g fresh soil) was incubated for $2 \mathrm{~h}$ at $37^{\circ} \mathrm{C}$ with $9 \mathrm{ml}$ of $0.1 \mathrm{M}$ Tris buffer and $1 \mathrm{ml}$ of the substrate solution. The reaction was stopped by the addition of $35 \mathrm{ml}$ of $2.5 \mathrm{M} \mathrm{KCl} / 0.32 \mathrm{mM}$ 
Table 1 The selected soil and microbial properties in adjacent natural secondary forest (SF) stands and larch plantation (LP) stands

\begin{tabular}{|c|c|c|c|c|c|c|c|c|}
\hline Sampling time & Soil depth $(\mathrm{cm})$ & Forest type & $\begin{array}{l}\text { Soil organic } \\
\mathrm{C}\left(\mathrm{g} \mathrm{kg}^{-1}\right)\end{array}$ & $\begin{array}{l}\text { Total N } \\
\left(\mathrm{g} \mathrm{kg}^{-1}\right)\end{array}$ & $\mathrm{C} / \mathrm{N}$ & $\begin{array}{l}\mathrm{MBC} \\
\left(\mathrm{mg} \mathrm{kg}^{-1}\right)\end{array}$ & $\begin{array}{l}\mathrm{MBN} \\
\left(\mathrm{mg} \mathrm{kg}^{-1}\right)\end{array}$ & Soil pH \\
\hline \multirow[t]{4}{*}{ Jun 2010} & \multirow[t]{2}{*}{$0-5$} & $\mathrm{SF}$ & $65.8 \pm 2.9^{*}$ & $6.0 \pm 0.3^{*}$ & $11.0 \pm 0.3$ & $958.6 \pm 71.3^{*}$ & $153.8 \pm 16.4^{*}$ & $6.3 \pm 0.2 *$ \\
\hline & & LP & $43.7 \pm 1.6$ & $3.9 \pm 0.2$ & $11.2 \pm 0.2$ & $562.7 \pm 25.3$ & $90.1 \pm 5.2$ & $5.4 \pm 0.1$ \\
\hline & \multirow[t]{2}{*}{$5-15$} & $\mathrm{SF}$ & $36.4 \pm 3.0^{*}$ & $3.6 \pm 0.4^{*}$ & $10.2 \pm 0.2$ & $548.0 \pm 55.5^{*}$ & $95.4 \pm 10.0^{*}$ & $5.8 \pm 0.2$ \\
\hline & & LP & $20.9 \pm 2.1$ & $2.1 \pm 0.3$ & $10.0 \pm 0.2$ & $353.0 \pm 20.9$ & $46.0 \pm 6.9$ & $5.3 \pm 0.1$ \\
\hline \multirow[t]{4}{*}{ Oct 2010} & \multirow[t]{2}{*}{$0-5$} & $\mathrm{SF}$ & $66.1 \pm 2.3^{*}$ & $6.0 \pm 0.3^{*}$ & $11.0 \pm 0.4$ & $737.9 \pm 58.1^{*}$ & $116.4 \pm 10.3^{*}$ & ND \\
\hline & & LP & $44.4 \pm 2.2$ & $4.1 \pm 0.3$ & $11.0 \pm 0.3$ & $410.6 \pm 12.3$ & $67.7 \pm 4.8$ & ND \\
\hline & \multirow[t]{2}{*}{$5-15$} & $\mathrm{SF}$ & $36.9 \pm 2.7^{*}$ & $3.7 \pm 0.3^{*}$ & $10.0 \pm 0.2$ & $392.6 \pm 32.6^{*}$ & $66.4 \pm 5.3^{*}$ & ND \\
\hline & & LP & $21.4 \pm 2.6$ & $2.2 \pm 0.3$ & $10.1 \pm 0.3$ & $243.0 \pm 13.5$ & $35.1 \pm 4.6$ & ND \\
\hline
\end{tabular}

$M B C$ microbial biomass $\mathrm{C} ; M B N$ microbial biomass $\mathrm{N}$. Values shown in tables are means \pm standard errors $(n=4)$. ND denotes not determined $* P<0.05$ levels, significant differences between the secondary forest and larch plantation of the corresponding depth

$\mathrm{Ag}_{2} \mathrm{SO}_{4}$ solution. The ammonia formed was distilled and collected in boric acid mixed indicator solution and titrated with $5 \mathrm{mM} \mathrm{H}_{2} \mathrm{SO}_{4}$. The L-asparaginase activity was expressed in micromoles of ammonium released per hour per gram of soil.

Protease activity was estimated by mixing $1.0 \mathrm{~g}$ fresh soil, $5 \mathrm{ml}$ of $50 \mathrm{mM}$ Tris buffer and $5 \mathrm{ml}$ of $2 \%$ sodium caseinate followed by incubation for $2 \mathrm{~h}$ at $50^{\circ} \mathrm{C}$ (Ladd and Butler 1972). The aromatic amino acids released during incubation were extracted with Folin-Ciocalteu's reagent and measured at $700 \mathrm{~nm}$. The enzyme activity was expressed in micromoles of tyrosine released per hour per gram of soil.

\subsection{Statistical analyses}

The data were analyzed using a split-plot analysis of variance (ANOVA) within the general linear procedure. Before analysis, data were tested for normality and homogeneity of error variances to determine whether transformations were needed. Pairwise comparisons were also made between forest types at each depth and between the different sampling depths. Pearson linear correlations were used to assess the relationships between the soil SON and the activities of enzymes (including $N$ acetyl- $\beta$-glucosaminidase, urease, L-asparaginase, and protease) and microbial biomass. The statistical analyses (a split-plot ANOVA, an ANOVA with a Tukey pairwise comparison and a Pearson correlation) were performed with SPSS 13.0 for Windows. Soil enzyme activities were expressed on a per soil $\mathrm{C}$ basis (specific enzyme activities) so that variations in enzyme activity could be related to the quality of soil organic matter.

\section{Results}

\subsection{Soil-soluble organic N}

The concentrations of soil SON extracted by water and hot water were examined in summer (June) and autumn (October) of 2010. The SON concentrations were significantly higher in the SF than those in the LP stands for both extractant types. Thus, we only presented the SON extracted by water in this paper.

In the $0-5 \mathrm{~cm}$ soil layer, the concentrations of soil SON ranged from $61.1 \mu \mathrm{g} \mathrm{g}^{-1}$ in the LP stands to $123.4 \mu \mathrm{g} \mathrm{g}^{-1}$ in the SF stands, comprising $53.4-73.0 \%$ of TSN and $1.5-2.1 \%$ of soil TN (Table 2). The SON concentrations in the SF stands were approximately 2-fold greater than those in the LP stands for the two sampling times in the $0-5 \mathrm{~cm}$ soil layer. In the 5 $15 \mathrm{~cm}$ soil layer, the values of SON ranged from 4.8 to $19.4 \mu \mathrm{g} \mathrm{g}^{-1}$, comprising $30.6-44.8 \%$ of TSN and $0.2-0.5 \%$ of soil TN, whereas there was no significant difference in the SON concentrations between the SF and the LP stands. In general, the SON/TSN and SON/TN ratios did not differ between the SF and LP stands for the two sampling times in the 0 to 5- and 5- to 15-cm layers. The concentrations of SON and ratios of SON/TSN and SON/TN were lower in the 5- to $15-\mathrm{cm}$ soil layer than in the 0 - to $5-\mathrm{cm}$ soil layer for both forest types. The data on inorganic $\mathrm{N}$ showed that the $\mathrm{NO}_{3}{ }^{-}-\mathrm{N}$ was the predominant form in both types of stands and decreased with soil depth. The $\mathrm{NH}_{4}{ }^{+}-\mathrm{N}$ concentrations did not differ significantly with forest type or soil depth (Table 2).

\subsection{Soil enzyme activities}

The soil enzyme activities were significantly greater in the SF stands than those in the LP stands in the 0 - to 5cm soil layer and decreased with the soil depth (Table 3). The significant difference in enzyme activities between the SF and LP stands was more pronounced in the 0- to $5-\mathrm{cm}$ soil layer. Specifically, the activities of urease and protease in the SF stands were approximately 2-fold greater than those in the LP stands in both soil layers, and the activities of $N$-acetyl- $\beta$-glucosaminidase and Lasparaginase were approximately 1.2 - and 1.7-fold greater, respectively, than those in the LP stands. The enzyme 
Table 2 Soil $\mathrm{NH}_{4}{ }^{+}-\mathrm{N}, \mathrm{NO}_{3}{ }^{-}-\mathrm{N}, \mathrm{SON}$ (soluble organic $\mathrm{N}$ ) in water extracts, SON/TSN (total soluble $\mathrm{N}$ ) and SON/TN (total N) in adjacent natural secondary forest (SF) stands and larch plantation (LP) stands

\begin{tabular}{|c|c|c|c|c|c|c|c|}
\hline Sampling time & Soil depth (cm) & Forest type & $\mathrm{SON}\left(\mu \mathrm{g} \mathrm{g}^{-1}\right)$ & $\mathrm{NH}_{4}^{+}-\mathrm{N}\left(\mu \mathrm{g} \mathrm{g}^{-1}\right)$ & $\mathrm{NO}_{3}{ }^{-}-\mathrm{N}\left(\mu \mathrm{g} \mathrm{g}^{-1}\right)$ & SON/TSN (\%) & SON/TN (\%) \\
\hline \multirow[t]{4}{*}{ Jun 2010} & $0-5$ & $\mathrm{SF}$ & $123.4 \pm 22.4^{*}$ & $6.3 \pm 0.9$ & $56.8 \pm 7.8$ & $64.9 \pm 4.0$ & $2.1 \pm 0.4$ \\
\hline & & LP & $71.1 \pm 25.5$ & $6.4 \pm 0.9$ & $39.7 \pm 3.1$ & $53.4 \pm 11.3$ & $1.8 \pm 0.3$ \\
\hline & $5-15$ & $\mathrm{SF}$ & $19.4 \pm 4.8$ & $5.4 \pm 0.3$ & $20.4 \pm 1.4^{*}$ & $41.0 \pm 6.8$ & $0.5 \pm 0.1$ \\
\hline & & LP & $7.4 \pm 1.7$ & $5.2 \pm 0.8$ & $10.9 \pm 1.3$ & $30.6 \pm 4.2$ & $0.4 \pm 0.1$ \\
\hline \multirow[t]{4}{*}{ Oct 2010} & $0-5$ & $\mathrm{SF}$ & $97.5 \pm 9.4^{*}$ & $1.9 \pm 0.3$ & $34.5 \pm 8.1$ & $73.0 \pm 4.4$ & $1.6 \pm 0.2$ \\
\hline & & LP & $61.1 \pm 5.5$ & $1.5 \pm 0.3$ & $25.3 \pm 1.2$ & $69.1 \pm 2.5$ & $1.5 \pm 0.2$ \\
\hline & $5-15$ & $\mathrm{SF}$ & $11.7 \pm 3.3$ & $1.7 \pm 0.2$ & $11.9 \pm 2.1 *$ & $44.8 \pm 7.5$ & $0.3 \pm 0.1$ \\
\hline & & LP & $4.8 \pm 1.1$ & $2.4 \pm 0.4$ & $6.4 \pm 0.7$ & $33.8 \pm 5.2$ & $0.2 \pm 0.0$ \\
\hline
\end{tabular}

Values shown in tables are means \pm standard errors $(n=4)$

$* P<0.05$ levels, significant differences between the secondary forest and larch plantation of the corresponding depth

activities showed trends similar to those observed for the SON at the two sampling times.

In the $0-$ to $5-\mathrm{cm}$ soil layer, the activity of protease was significantly higher and the activity of $N$-acetyl- $\beta$-glucosaminidase was significantly lower if expressed on a soil organic $\mathrm{C}$ basis in the SF stands than in the LP stands, whereas the activities of urease and L-asparaginase per unit soil organic C were comparable between the two forest types (Table 3). All the enzyme activities per unit soil organic $\mathrm{C}$ were lower in the 5 - to $15-\mathrm{cm}$ soil layer than in the 0 - to 5 -cm soil layer for both forest types in October 2010 (with the exception of urease in the 5- to $15-\mathrm{cm}$ soil layer in the LP stands).

\subsection{Relationships between soil SON and enzyme activities} and microbial biomass

For each sampling time (June or October 2010), the concentrations of soil SON were positively correlated with the soil $\mathrm{N}$ acetyl- $\beta$-glucosaminidase, urease, L-asparaginase, and protease activities per unit soil mass in both the SF and the LP stands (Fig. 1; $P<0.01, n=16$ ). The concentrations of SON were correlated with the enzyme activities per unit soil organic $\mathrm{C}$ according to the sampling time. Specifically, significant and positive correlations were found for soil SON pools and enzyme activities in October 2010 but not in June 2010 (Fig. 2). A strong positive correlation was found between SON and microbial biomass $\mathrm{C}$ and between $\mathrm{SON}$ and microbial biomass $\mathrm{N}$ at both sampling times (Fig. 3).

\section{Discussion}

Our results demonstrate that the two forest types differ markedly in soil SON. The differences in soil SON concentrations appeared to be related to the amount of N-degrading enzymes per unit soil mass regardless of sampling time. An overall feature of our results was that the modification of the soil enzyme-catalyzed reaction rates involved in $\mathrm{N}$ cycling could partially explain the difference in the concentrations of SON between the SF and the LP stands.

Compared with the LP stands, the SF stands showed higher SON concentrations, and this trend was more pronounced in the top soil layer. This finding is consistent with those of previous studies in temperate forest regions (Zhong and Makeschin 2003) and subtropical forest regions (Burton et al. 2007a). However, the SON concentration found in our study area, particularly in the 0 - to 5-cm soil layer, is much higher than that reported from other temperate forests (Zhong and Makeschin 2003). The soil sampling strategy (number of samples over space and time), sample preparation (sieving and drying), soil storage, and soil solution extraction technique are all known to influence soil SON concentrations (Jones and Willett 2006). In addition, the specific characteristics of tree species could also affect the uptake of soil SON; and then affect the soil SON concentration in the forest stand. Scott and Rothstein (2011) reported that the tree species growing in the low-fertility habitats preferred simple organic $\mathrm{N}$ (amino acids) than those growing in the high-fertility habitats for the temperate forests. The soil $\mathrm{NH}_{4}{ }^{+}-\mathrm{N}$ and $\mathrm{NO}_{3}{ }^{-}-\mathrm{N}$ did not differ significantly between the SF and LP stands in the $0-$ to $5-\mathrm{cm}$ soil layer. This result was inconsistent with the findings of a previous study of forest ecosystems by Burton et al. (2007b) and indicated that soil $\mathrm{SON}$ is more sensitive than inorganic $\mathrm{N}$ as an indicator of $\mathrm{N}$ availability for the two forest types. We found that the ratios of SON/TSN and SON/TN were comparable between the two forest types. This finding suggests that the processes regulating the three N pools (SON, TSN, TN) are at least partially coupled. A significant correlation between the SON and soil total N $(P<$ 0.01 ) supports this hypothesis (data not shown).

A variety of factors have been identified in the literature as influences on the changes in the soil SON for the two forest types. For example, differences in the rate of litter input, root production and root exudates due to changes in species composition may be the primary drivers that alter the soil SON 


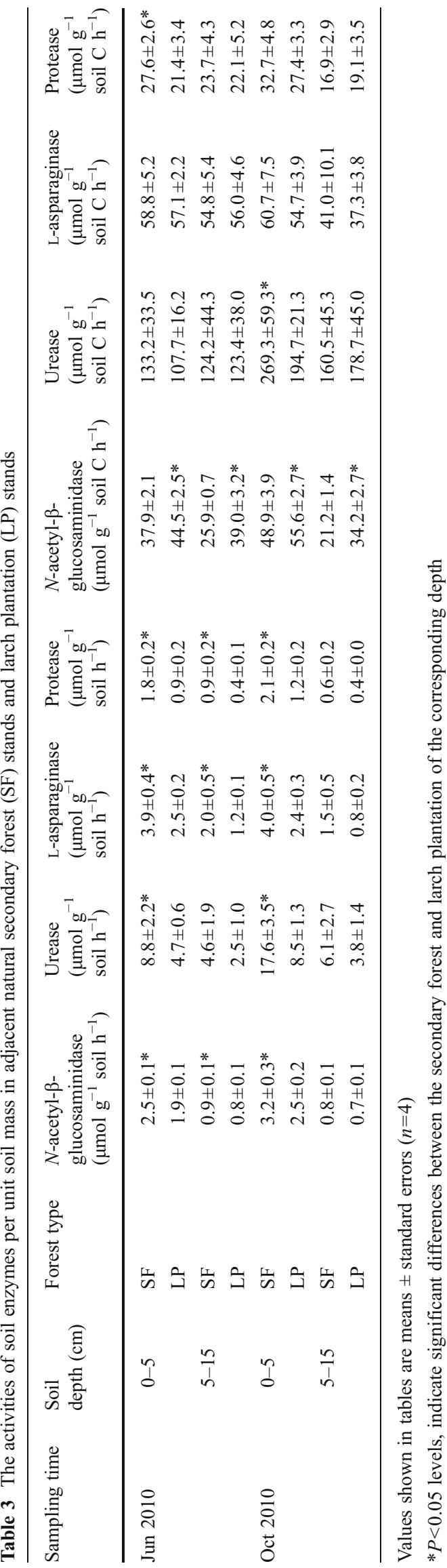
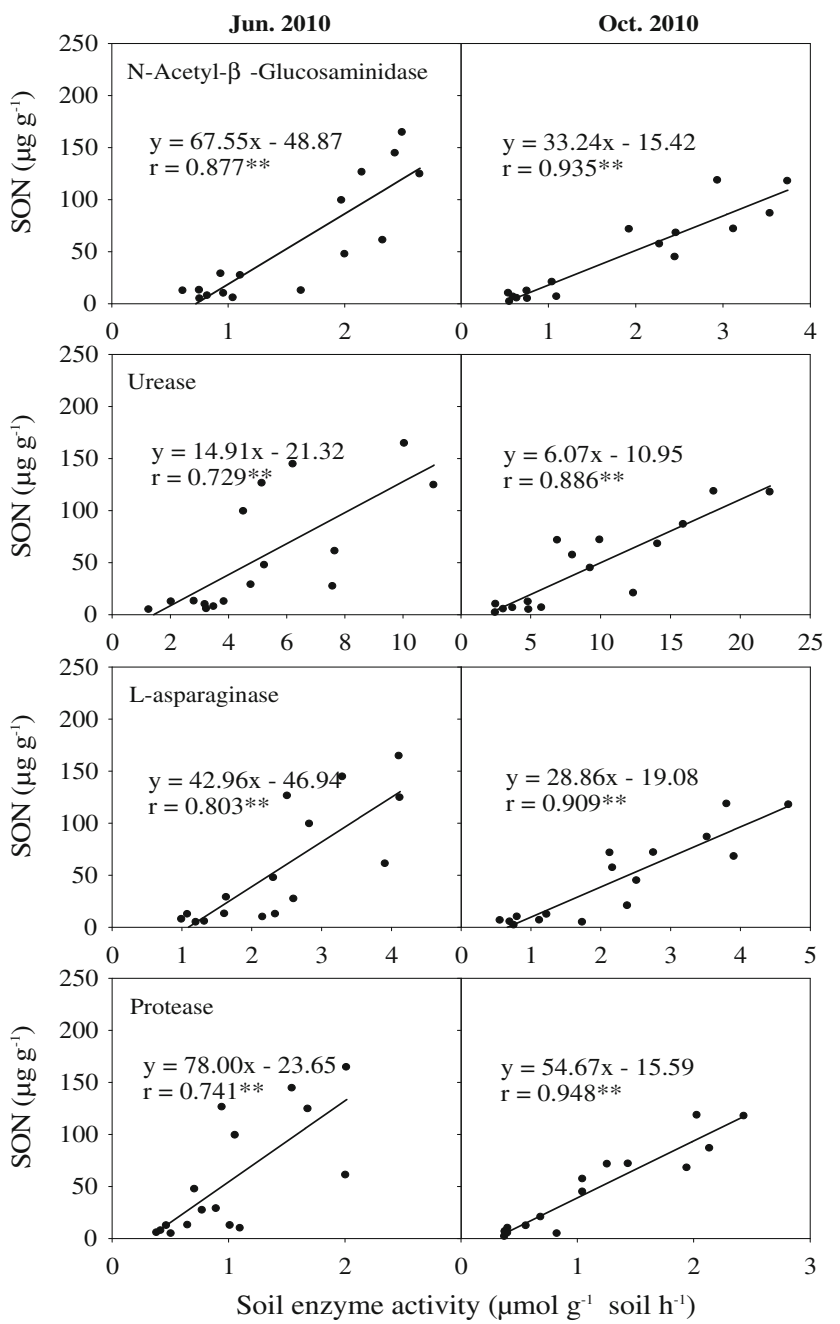

Fig. 1 Relationships between soil soluble organic $\mathrm{N}$ and $N$-acetyl- $\beta$ glucosaminidase, urease, asparaginase, and protease per unit soil mass for the natural secondary forest and the larch plantation $(n=16$, i.e., four plots $\times$ two soil depths $\times$ two forest types). ${ }^{* * P} P 0.01$, significance

(Burton et al. 2007a; Smolander and Kitunen 2002). In addition, soil microbial activity and turnover can influence soil SON concentrations and subsequently soil $\mathrm{N}$ cycling through mineralization-immobilization processes (Cookson et al. 2007). However, changes in soil $\mathrm{N}$ mineralization between the SF and LP stands could also influence the soil SON pools (data not shown). In our study area, the SF stands had significantly higher leaf litter and fine root production than the LP stands (Yang et al. 2010). This result helps to explain the effects of the vegetation type on the soil SON. However, these changes in SON pools were not based on the soil $\mathrm{C} / \mathrm{N}$ ratios because the $\mathrm{C} / \mathrm{N}$ was relatively stable in the same soil layer for the two forest types. Therefore, the differences in the amount of leaf litter and root biomass partially explain the effects of the forest type on the soil SON concentrations.

Soil enzyme activities are the chief driving factors for organic matter decomposition and $\mathrm{N}$ transformation in soil, 

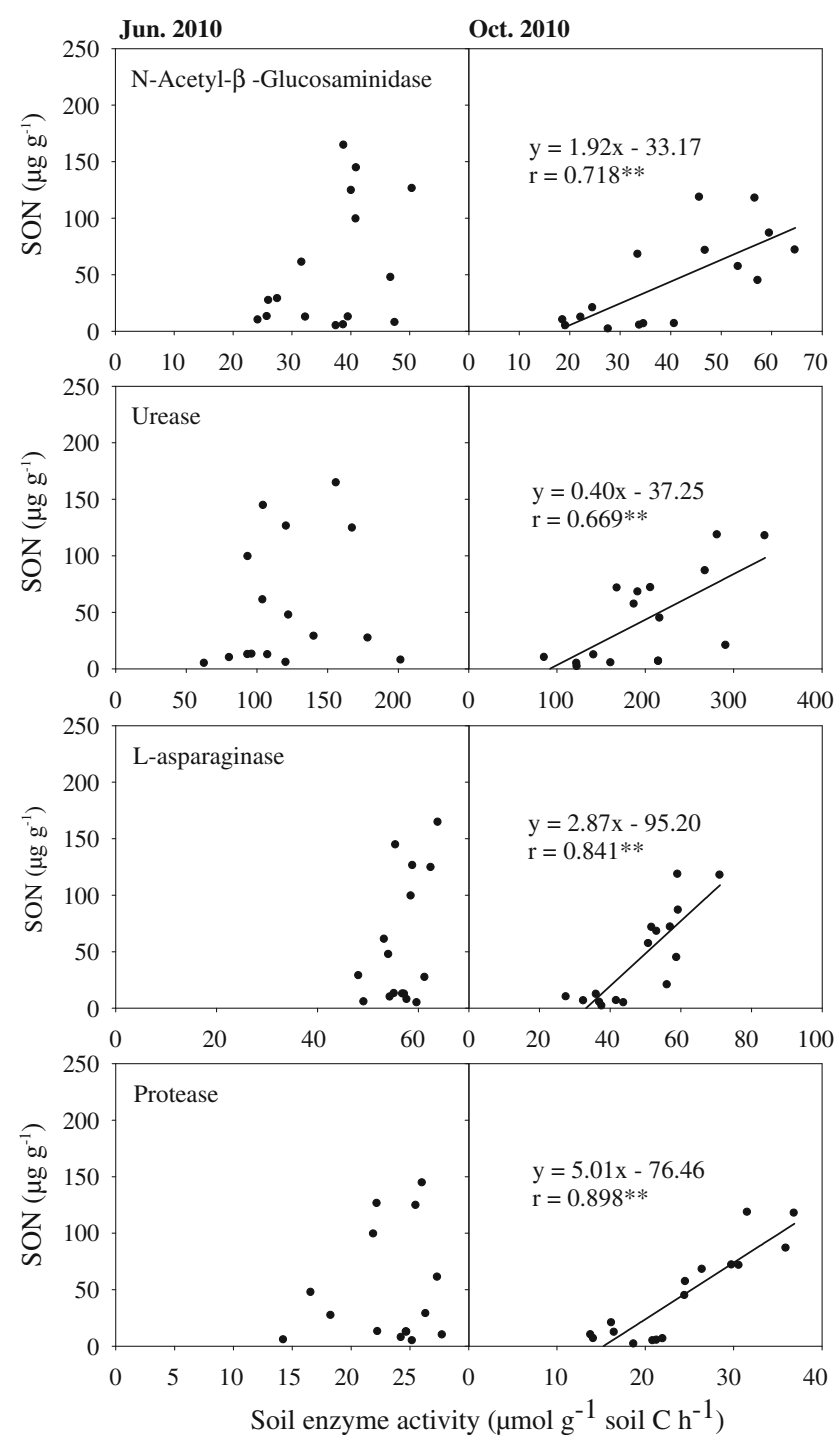

Fig. 2 Relationships between soil soluble organic $\mathrm{N}$ and $N$-acetyl- $\beta$ glucosaminidase, urease, asparaginase, and protease per unit soil organic $\mathrm{C}$ for the natural secondary forest and the larch plantation $(n=16$, i.e., four plots $\times$ two soil depths $\times$ two forest types). ${ }^{* *} P<0.01$, significance

and changes in the activities of N-degrading enzymes will affect the soil $\mathrm{N}$ availability. For example, protease is involved in the degradation of proteins to peptides, and urease may hydrolyze urea into $\mathrm{NH}_{4}{ }^{+}-\mathrm{N}$ (Tabatabai 1994). In accordance with the soil SON concentrations, the soil enzyme activities per unit soil mass were higher in the SF stands than those in the LP stands. In the last decade, the new paradigm indicated that the key point in the $\mathrm{N}$ cycle is the depolymerization of $\mathrm{N}$ containing compounds (Schimel and Bennett 2004). Generally, the complex organic polymers are too large to be immediately bioavailable; but they can be depolymerized by enzymes to release simple organic $\mathrm{N}$, such as amino acids, amino sugars, which are bioavailable $\mathrm{N}$ for plant uptake. Our results indicated that enzyme activities were critical factors that influence $\mathrm{N}$ availability, especially soluble organic nitrogen, for
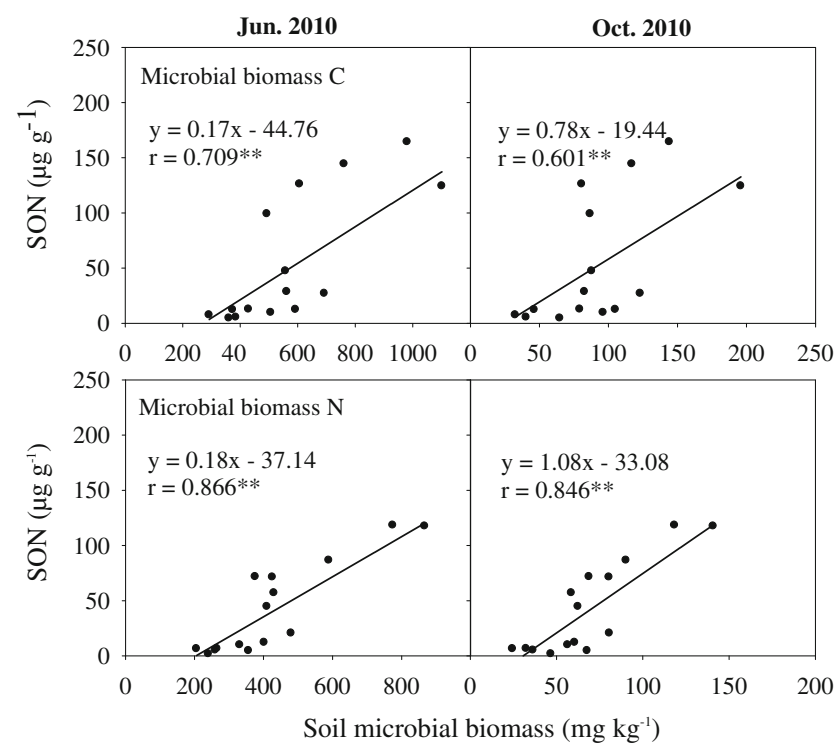

Fig. 3 Relationships between soil soluble organic $\mathrm{N}$ and microbial biomass $\mathrm{C}$, microbial biomass $\mathrm{N}$ for the natural secondary forest and the larch plantation $(n=16$, i.e., four plots $\times$ two soil depths $\times$ two forest types). ${ }^{* * P} P 0.01$, significance

both the forest types. However, the specific enzyme activities (calculated on an organic $\mathrm{C}$ basis) varied with the forest type. Our results indicate that factors other than the soil organic $\mathrm{C}$ contents are important in influencing certain $\mathrm{N}$-degrading enzymes. It is generally considered that microbial biomass changes were occurring simultaneously with shifts in enzyme activity (Allison et al. 2007). The soil microbial biomass, microbial activity or microbial community composition may be the crucial factor affecting soil enzyme activities (Cookson et al. 2007; Sinsabaugh et al. 1991). Šnajdr et al. (2008) showed that differences in enzyme activities were accompanied by differences in the microbial community composition in the upper layers of Quercus petraeu forest soil. In contrast, Lucas et al. (2007) found that small additions of N-containing organic compounds can cause changes in the structure of the soil microbial community but that community changes do not necessarily impact enzyme activities. Consequently, the direction of soil-enzyme effects on SON may depend on the microbial species as well as the microbial biomass and activity present in different ecosystems.

The observed differences in the concentrations of the soil SON between the SF stands and the LP stands have been relatively well explained by the variation in enzyme activities per unit soil mass. Correlations between soil SON and enzyme activities per unit soil mass were also observed in other studies (Xing et al. 2010). Such results suggest that the production of soil SON was strongly affected by Ndegrading enzymes although a portion of the SON was produced by plants, roots and microorganisms. For example, the activities of urease and protease in the SF stands 
were approximately 2 -fold greater than those in the LP stands, and corresponding differences in soil SON were found between the two forest types. Note that the predominance of soil enzyme activities is strongly related to the ecological role and kinetic characteristics of the enzymes studied regardless of the effects of soil physiochemical properties (Tabatabai 1994). In our study area, urease activity was more predominant than the activities of $N$-acetyl- $\beta$ glucosaminidase, protease, and L-asparaginase for both forest types. This result was consistent with the results of previous studies in subtropical forest ecosystems by Xing et al. (2010). Additions of different $\mathrm{N}$-degrading enzymes to soils could further demonstrate the effect of the modification of the soil enzyme-catalyzed reaction rates on soil SON. To our knowledge, however, no previous reports addressed the relationship between soil specific enzyme activity and soil SON. In our study, soil SON was correlated with specific enzyme activity for the two forest types in a way that depended on the sampling time. This result indicates that the measurements of specific enzyme activity lacked sufficient resolution to differentiate the changes in soil SON between the SF stands and LP stands.

In general, the trends in the change in the soil SON pools and enzyme activities per unit soil mass with forest type were consistent for the two sampling times (i.e., June 2010 and October 2010). Significant and positive correlations were also found for the soil SON pools and enzyme activities per unit soil mass for each sampling time, indicating that the association between soil SON and N-degrading enzyme activity was not obscured by the seasonal fluctuation in soil SON, enzyme activity or both caused by the soil environment.

In conclusion, the natural secondary forests are more effective than the larch plantations at maintaining soil $\mathrm{N}$ availability, especially soluble organic $\mathrm{N}$. The relationships between soil SON and enzyme activities are independent on sampling time. The soil enzyme activity is the crucial factor for $\mathrm{N}$ transformation in the soil. Reductions in these enzyme activities may be a factor that limits the soil SON. Accordingly, a better understanding of the microbial properties involved in the dynamics of soil SON, such as microbial activity and community composition, would yield further insights into the ways in which SON pools are influenced by enzyme activities.

Acknowledgments We thank Guangqi Zhang for assistance with the field investigation and Osbert J. Sun for helpful comments on a previous version of the manuscript.

Funding This research was supported by the National Basic Research Program of China (2011CB403205), the CAS/SAFEA International Partnership Program for Creative Research Teams (KZCX2-YW-445), and the National Non-commercial Forests Project (200804027-05).

\section{References}

Allison VJ, Condron LM, Peltzer DA, Richardson SJ, Turner BL (2007) Changes in enzyme activities and soil microbial community composition along carbon and nutrient gradients at the Franz Josef chronosequence, New Zealand. Soil Biol Biochem 39: $1770-1781$

Boerner REJ, Brinkman JA, Smith A (2005) Seasonal variations in enzyme activity and organic carbon in soil of a burned and unburned hardwood forest. Soil Biol Biochem 37:1419-1426

Booth MS, Starks JM, Rastetter E (2005) Controls on nitrogen cycling in terrestrial ecosystems: a synthetic analysis of literature data. Ecol Monogr 75:139-157

Brookes PC, Landman A, Pruden G, Jenkinson DS (1985) Chloroform fumigation and the release of soil nitrogen: a rapid direct extraction method to measure microbial biomass nitrogen in soil. Soil Biol Biochem 17:837-842

Burton J, Chen CR, Xu ZH, Ghadiri H (2007a) Soluble organic nitrogen pools in adjacent native and plantation forests of subtropical Australia. Soil Biol Biochem 39:2723-2734

Burton J, Chen CR, Xu ZH, Ghadiri H (2007b) Gross nitrogen transformations in adjacent native and plantation forests of subtropical Australia. Soil Biol Biochem 39:426-433

Chen CR, Xu ZH (2008) Analysis and behavior of soluble organic nitrogen in forest soils. J Soils Sediments 8:363-378

Chen CR, Xu ZH, Keay P, Zhang SL (2005) Total soluble nitrogen in forest soils as determined by persulfate oxidation and by high temperature catalytic oxidation. Aust J Soil Res 43:515-523

Cookson WR, Osman M, Marschner P, Abaye DA, Clark I, Murphy DV, Stockdale EA, Watson CA (2007) Controls on soil nitrogen cycling and microbial community composition across land use and incubation temperature. Soil Biol Biochem 39:744-756

Farrell M, Hill PW, Wanniarachchi SD, Farrar J, Bardgett RD, Jones DL (2011) Rapid peptide metabolism: a major component of soil nitrogen cycling? Global Biogeochem Cycles 25:11

Frankenberger WT Jr, Tabatabai MA (1991) L-Asparaginase activity of soils. Biol Fertil Soils 11:6-12

Freeman C, Ostle N, Kang H (2001) An enzyme 'latch' on a global carbon store. Nature 409:149

Jones DL, Willett VB (2006) Experimental evaluation of methods to quantify dissolved organic nitrogen (DON) and dissolved organic carbon (DOC) in soil. Soil Biol Biochem 38:991-999

Kalbitz K, Solinger S, Park JH, Michalzik B, Matzner E (2000) Controls on the dynamics of dissolved organic matter in soils: a review. Soil Sci 165:277-304

Kaye JP, Hart SC (1997) Competition for nitrogen between plants and soil microorganisms. Trends Ecol Evol 12:139-143

Kranabetter JM, Dawson CR, Dunn DE (2007) Indices of dissolved organic nitrogen, ammonium and nitrate across productivity gradients of boreal forests. Soil Biol Biochem 39:3147-3158

Ladd JN, Butler JHA (1972) Short-term assays of soil proteolytic enzyme activities using proteins and dipeptide derivatives as substrates. Soil Biol Biochem 4:19-30

LeDuc SD, Rothstein DE (2010) Plant-available organic and mineral nitrogen shift in dominance with forest stand age. Ecology 91:708-720

Lucas RW, Casper BB, Jackson JK, Balser TC (2007) Soil microbial communities and extracellular enzyme activity in the New Jersey Pinelands. Soil Biol Biochem 39:2508-2519

Murphy DV, Macdonald AJ, Stockdale EA, Goulding KWT, Fortune S, Gaunt JL, Poulton PR, Wakefield JA, Webster CP, Wilmer WS (2000) Soluble organic nitrogen in agricultural soil. Biol Fertil Soils 30:374-387

Näsholm T, Ekblad A, Nordin A, Giesler R, Högberg M, Högberg P (1998) Boreal forest plants take up organic nitrogen. Nature 392:914-916 
Neff JC, Chapin FS III, Vitousek PM (2003) Breaks in the cycle: dissolved organic nitrogen in terrestrial ecosystems. Front Ecol Environ 1:205-211

Schimel JP, Bennett J (2004) Nitrogen mineralization: challenges of a changing paradigm. Ecology 85:591-602

Scott EE, Rothstein DE (2011) Amino acid uptake by temperate tree species characteristic of low- and high-fertility habitats. Oecologia 167:547-557

Sinsabaugh RL, Antibus RK, Linkins AE (1991) An enzymic approach to the analysis of microbial activity during plant litter decomposition. Agric Ecosyst Environ 34:43-54

Sinsabaugh RL, Lauber CL, Weintraub MN, Ahmed B, Allison SD, Crenshaw C, Cusack D, Frey S, Gallo ME, Gartner TB, Hobbie SE, Holland K, Keeler BL, Powers JS, Stursova M, TakacsVesbach C, Waldrop MP, Wallenstein MD, Zak DR, Zeglin LH (2008) Stoichiometry of soil enzyme activity at global scale. Ecol Lett 11:1252-1264

Smolander A, Kitunen V (2002) Soil microbial activities and characteristics of dissolved organic $\mathrm{C}$ and $\mathrm{N}$ in relation to tree species. Soil Biol Biochem 34:651-660

Šnajdr J, Valášková V, Merhautová V, Herinková J, Cajthaml T, Baldrian P (2008) Spatial variability of enzyme activities and microbial biomass in the upper layers of Quercus petraea forest soil. Soil Biol Biochem 40:2068-2075

Tabatabai MA (1994) Soil enzymes. In: Weaver RW, Angle JS, Bottomley PS (eds) Methods of soil analysis: microbiological and biochemical properties. Part 2. Soil Science Society of America, Madison, pp $775-833$
Tabatabai MA, Bremner JM (1972) Assay of urease activity in soils. Soil Biol Biochem 4:479-487

Vance ED, Brookes PC, Jenkinson DS (1987) An extraction method for measuring soil microbial biomass C. Soil Biol Biochem 19:703-707

Weand MP, Arthur MA, Lovett GM, McCulley RL, Weathers KC (2010) Effects of tree species and $\mathrm{N}$ additions on forest floor microbial communities and extracellular enzyme activities. Soil Biol Biochem 42:2161-2173

Xing SH, Chen CR, Zhou BQ, Zhang H, Nang ZM, Xu ZH (2010) Soil soluble organic nitrogen and active microbial characteristics under adjacent coniferous and broadleaf plantation forests. J Soils Sediments 10:748-757

Yang K, Zhu JJ, Zhang M, Yan QL, Sun OJ (2010) Soil microbial biomass carbon and nitrogen in forest ecosystems of Northeast China: a comparison between natural secondary forest and larch plantation. J Plant Ecol 3:175-182

Yu Z, Zhang Q, Kraus TEC, Dahlgren RA, Anastasio C, Zasoski RJ (2002) Contribution of amino compounds to dissolved organic nitrogen in forest soils. Biogeochemistry 61:173-198

Zhong ZK, Makeschin F (2003) Soluble organic nitrogen in temperate forest soils. Soil Biol Biochem 35:333-338

Zhu WX, Carreiro MM (2004) Variations of soluble organic nitrogen and microbial nitrogen in deciduous forest soils along an urban-rural gradient. Soil Biol Biochem 36:279-288

Zhu JJ, Mao ZH, Hu LL, Zhang JX (2007) Plant diversity of secondary forests in response to anthropogenic disturbance levels in montane regions of northeastern China. J Forest Res 12:403-416 